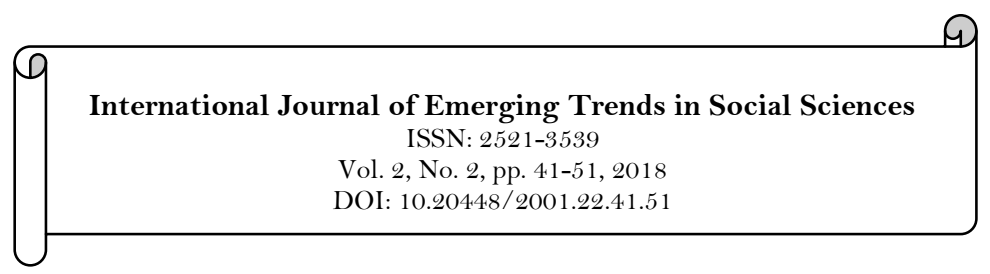

\title{
Trump Administration's Initiatives in Resolving North Korea's Nuclear Problem: Cooperative Threat Reduction (CTR) Approach
}

\author{
Youngshik Kim ${ }^{1}$ \\ Chonghee $\mathrm{Han}^{2}$ \& \\ ${ }^{1}$ Professor emeritus, PhD Department of Public Administration Sejong University, Seoul Korea. \\ - 2 Professor, PhD Department of Public Administration Kwangwoon University, Seoul Korea. \\ Email:hchong99@kw.ac.kr
}

\begin{abstract}
The purpose of the paper is to review the applicability of the Cooperative Threat Reduction (CTR), the so-called Nunn-Lugar program to North Korea in an effort to denuclearize the country. To this end, it focuses on analysis of some US scholars and experts' initiatives on that program based on lessons learned from the former Soviet Union to set the ground rules for resolving North Korea's nuclear issues because the US has been a salient country able to serve as an engine of non-proliferation and expertise that can be used around world. This article argues that the ground rules should be built in terms of clarifying the concept of threats, identifying the means of strike capability, and choosing the participants and their roles in the negotiation in order to increase the possibility of success for the CTR program on North Korea. In line with these principles, US-Republic of Korea (ROK) coordination would be crucial, despite of obstacles like DPRK's objection of ROK's involvement in this process of bilateral engagement between US and DPRK. The ROK would need to be more actively engaged in the CTR program with the help of financial resources as well as technical assistance that could make a soft landing for North Korea's CTR program, as the Korean Energy Development Organization (KEDO) during the mid-1990s envisioned. It is more likely to apply this approach to North Korea's nuclear program and to achieve a good result in resolving North Korean nuclear problems by the active participation of the two co-sponsor and co-initiator of CTR model, Nunn and Lugar, into the discussions in the administration of President Trump.
\end{abstract}

\author{
Keywords: \\ Cooperative threat reduction \\ Nunn-Lugar program \\ North Korea's \\ denuclearization. \\ Licensed: \\ This work is licensed under a \\ Creative Commons Attribution \\ 4.0 License. \\ Acknowledgement \\ This work was made possible \\ during the Han's sabbatical year \\ of Kwangwoon University in \\ 2017 \\ Publisher: \\ Scientific Publishing Institute
}

\section{Introduction}

In geo-political terms, the Korean peninsula, situated as a buffer zone between continental and ocean powers, historically suffered from the expansion policies of the dominating power at many times. The US has been engaged in the peninsula since the 1950s, based on a balance of power theory, and contributed to security and stability in north-east Asia.

Given the traditional power rivalry of neighboring countries, nuclear confrontation between the US and North Korea is complicating the power nexus in this region, casting a bleak outlook on the possible reunification of the peninsula.

South Koreans, who have enjoyed economic advantage over the North Korean regime, shocked by the recent North's 5th nuclear tests, especially among their conservative leaders, could not even conceive of proposing a conversation on rapprochement to their counterparts. Those Presidents of the conservative parties since 2007, despite their rosy visions of a unified Korea, could not have ushered in substantial progress by their talk of conciliation between the two Koreas, emphasizing only the importance of denuclearization of North Korea.

In their one chance for talking between the North-South military authorities, held in October 2014, the Southern part proposed an agenda of denuclearization and confidence building measures, but Northern part, 
disregarding those agenda of the South, raised the problem of replacing the armistice agreement with the peace agreement, and criticized the southern government's propaganda policy against the North Korean regime.

The North-South relations are deadlocked, have cut off all the communication lines, including the shutdown of Kaesung Industrial Complex on February 10, 2016, are exchanging only threats of bombing their counter part's main city areas. South Korea, which would be under the conservative regime, until the presidential election in May 2017, seems to have no possibility of proposing or accepting a dialogue between the two countries. The political situation, however, has turned around to a positive environment for the relations between the two Koreas after the election of President Moon, a progressive.

On the other hand, the incoming Secretary of Defense, Matttis, in a hearing in the Senate, on January 12 2017, said he was going to adopt a cautious approach toward North Korea, in terms of resolving the impasse with North Korea, and was going to look at their negotiating stances and work together with the State Department, carefully mingling with a call for diplomacy (Kirk, 2017).

In his address of 8 September 2016, celebrating 25 years of creating the Cooperative Threat Reduction (CTR) programs, former Senator Lugar expressed his concern about nuclear weapon program of North Korea, and said he is willing to go anywhere to prevent the proliferation of Weapons of Mass Destruction (WMD) (Lugar, 2016).

Even now, Richard Haass, President of the Council on Foreign Relations, is rating, high the strategic importance of the Korean peninsula, saying that the US military would remain on the peninsula after the unification (Haass, 2016). President Trump remarked at the press conference

with the Prime Minister of Japan, Mr. Shinzo Abe on 10 February 2017, that he considered defense against the North Korean missiles and nuclear threat to a high priority. ${ }^{1}$ In a joint communique signed on 30 June 2017, after their first talks between two Presidents, Trump and Moon, United States of America and Republic of Korea, the two summits agreed to deal with the threat of North Korea's nuclear program as a highest priority policy matter (Yonhap News Agency, 2017).

\section{CTR Studies on the Korean Peninsula}

The CTR program was initiated as Nunn-Lugar in 1991 in the US Congress which officially established the CTR program as the Soviet Nuclear Threat Reduction Act by Senators Nunn and Lugar. It was renamed in 1993 as Cooperative Threat Reduction and was evaluated as a success (Miller, 1995) reducing nuclear arsenals in Russia from 30,000 in 1991 to about 12,000 warheads today, with the US Congress funding 10,562.1 million dollars from 1991 to 2016 (Walker, 2016).

According to Ashton Carter, this was a major historic achievement for mankind and through Nunn-Lugar nuclear disaster was averted (Carter, 2005). Around 1996, the activities of the CTR program in Russia were almost finished with success, but then there arose the problem of expanding the program to non-Russian areas like Albania and Libya.

The Nunn-Lugar Expansion Act in 2003 opened this program to states other than former the Soviet Union.

But before the US Congress authorized funding that program in non-Russian areas, the problem of applying the program to the Korean peninsula was raised in the conferences of scholars, like that in the Center for Strategic and International Studies (CSIS) in December 2005.

In March 2001, DFI International, which had supported the Defense Threat Reduction Agency (DTRA), an agency of the US Department of Defense since 1999, opined that CTR could offer the means of facilitating a US-North Korean agreement to eliminate Pyongyang's ballistic missile program and also provide security for ultimately terminating North Korea's WMD assets during a normalization of relations between the North and South (DFI International, 2001).

Joel Wit and his colleagues considered the Korean Peninsula Energy Development Organization (KEDO), which was established by the US-North Korean Agreement in 1994, as a new model of CTR (Wit, Wolfsthal, \& Choong-suk, 2005).

Stephen Bosworth, as the first employee of KEDO, who was asked by the State Department's Tom Hubbard about his willingness to direct the institution, said in his interview in July 2012, that the Republican Administration at that time was not supportive of KEDO (Bermudez, 2013). Note that, although there is an Office of CTR in the State Department, there is no mission for reducing threats in the Defense Department.

The Defense Threat Reduction Agency, which does have a function of reducing threats, was created in 1998. To apply the CTR approach to North Korea, it is essential to expand areas of possible application. However, CTR funding cannot be used in countries under US sanctions.

${ }^{1}$ White House Office of the Press Secretary, “Joint Statement from President Donald J. Trump and Prime Minister Shinzo Abe," February 10, 2017, https://www.whitehouse.gov/the-press-office/2017/02/10/joint-statement-president-donald-j-trump-and-prime-minister-shinzo-abe (accessed February 20, 2017). 


\subsection{A New Approach to North Korea's Nuclear Problems}

Around 2005, there was new speculation about a way to tackle North Korea's nuclear problems. As mentioned above, starting with Joel Wit, there appeared some articles about those issues, like that of (Cerami, 2005).

In Wit et al. (2005) published by the Center for Strategic \& International Studies (CSIS), "The Six Party Talks and Beyond: Cooperative Threat Reduction and North Korea," they explained the CTR with no reference to the background, not mentioning the Nunn-Lugar Act.

They analyzed the positions of supporters and skeptics about applying CTR to North Korea, but in general they were more prone to assess its application pessimistically, resembling the US Congress's skeptical attitude on funding on North Korea. In their doubtful assessment of the CTR program on North Korea, they would be more hopeful about the Six Party Talks and its positive effect on the CTR program on North Korea.

For dealing with North Korea's nuclear issues, Joel Wilt continuously included Japan and the EU in the process of negotiation, especially in sharing the burden of funds.

He intentionally used the participating countries as being more like partners working with a host state in the negotiations and did not take into account the position or role of the Republic of Korea government. It is notable that in a report to the National Academy of Sciences, Harrington and DeThomas emphasized that "as the number of participants increases, the task of this grows" (Harrington \& Joseph, 2010) and also that "the International Standard Text Code (ISTC) could have begun operations six months earlier if it had not been for a late EU decision to insist on agreement texts in all EU languages, rather than in Russian and English as originally agreed" (Harrington \& Joseph, 2010).

This problem of complexity was also pointed out as something to be overcome that conflicting objectives and priorities within participating states in any attempt to eliminate WMDs would be manifested.

On top of that, the lack of institutions and established planning in the negotiation field has always necessitated extensive coordination between partners (Bleek, Chen, \& Joshua, 2016). In line with these points of view that could lead to effective negotiation, a few things need to be considered important in understanding and learning the lessons of CTR in Russia that could be applied to the North Korean case. Firstly, clarifying the concept of threats matters.

In applying the CTR program, it is crucial to grasp the meaning of "threat". In the Russian case, the threat was clear, because nuclear weapons were limited to those formerly possessed by the Soviet Union. It may be useful to differentiate the terms "danger" from "threat". Simply possessing some arms does not constitute a threat, but can be a danger to somebody.

If someone or one group uses his arms to threaten another's life or security, it can become a threat. Secondly, indentifying the means of strike capability is also essential. In terms of being elements of threat, nuclear weapons, in particular, can be divided into warheads and missiles.

In the case of North Korea, Intercontinental Ballistic Missiles (ICBM) would be needed to attack the US nuclear warheads, and missiles would be essential in forming real threats to the US. It can be said around 2016 that there gloomed the possibility of North Korea striking at the US after its fifth nuclear test, in September 2016. Lastly, choosing the participants and their roles in the negotiations is to be taken into account. The US CTR engagement in former Soviet areas was in most cases based on bilateral relations, like the US-Uzbek ones.

Yet, in CTR 2.0, multiple countries are involved, because of the funds needed to implement the CTR programs. According to the National Academy of Sciences in 2009, CTR 2.0 was presented as a new model for CTR for the North Korean case, with the central role of the US Department of Defense working together with four countries, including Russia, China, South Korea, and Japan, as its partners (National Academy of Sciences, 2009). But Stephan Bosworth, on 19 July 2012, argued that in the KEDO there arouse the problems of cultural gaps among the partners, and he indicated that in particular Japan, raising the issue of Japanese people abducted by North Korea, was not positive in engaging with North Korea (Bosworth, 2012). Likewise, Jungmin Kang pointed out various conflicts that might emerge between the North and South as well as between the individual countries involved (2009).

\subsection{North Korea's Position about their Nuclear Programs}

Since last year, North Korea has been negatively responding to the Six-Party Talks and insisting on having nuclear talks with the US Choe Sun-hui, Deputy Director General of American Affairs, Foreign Minister of North Korea, declared that Pyongyang had seen the Six-Party Talks framework as dead. Accordingly, in a North Korean Foreign Ministry spokesperson's statement on April 30 2016, the September 19 Joint Statement from the talks in 2005 had finally perished (Kim, 2016). 
Some skeptics, like Joel Wit, cast doubt on the possibility of North Korea's giving up their nuclear program. In spite of such pessimistic points of view, considering that North Korea's long-standing claim on the necessity for their nuclear program is based on their concern that their security has been threatened by the US forces' annual military drills in and around the Korean peninsula, the possibility of their call for a quid pro quo, compensation for renouncing the nuclear weapons could be presumed to exist as a bargaining chip.

The North Korean regime has been demanding that the US conclude their peace agreement and establish normal diplomatic relations between the two countries. Stephen Bosworth and William Perry are sharing the opinion that it was the Bush Administration that cut off, in March 2000, the dialogue with North Korea. Perry, former US Secretary of Defense, attributing the failure of the Six Party Talks to the US misconception of North Korea's objective or their way of thinking, suggested that more realistic policies are needed to deal with the communist country's growing threat (Perry, 2017).

Carterr and William (2000) revealed that they were determined to implement the Senator's vision, which was at that time a case of Arms Control. But in his recent interview with Joel Wit, in January 2017, Perry criticized the US deterrence strategy against North Korea's threat to test ICBMs and put emphasis on the uselessness of deterrence without knowing the country's real objectives such as survival, recognition, and improvement of Economy.

Perry, enumerating alternative plans against North Korea like surgical striking, intercepting, or disrupting, said that he would not recommend what he had come up with before in the article with Carter "If Necessary, Strike and Destroy" (Washington Post, 2016) because of its devastating effect on South Korea. Strategically, he advised a negotiation as an essential starting step, opposing the Six-Party Talks calling on North Korea to give up its nuclear weapons.

This means that a much more realistic approach to the nuclear weapons puzzle in North Korea should focus on the feasibility of the reduction of threats. Furthermore, he stressed the importance of American "Extended Deterrence" not as a defensive meaning or as a sign of strength, but to give a clear message of responding to a North Korean challenge by demonstrating the possible use of the US strategic assets. Citing the case of 2000, when North Korea showed interest in negotiations with the United States' proposed nonproliferation and suspended the nuclear test, Perry, however, said that the simple suspension of the USSouth Korean annual military exercises would not be acceptable enough as a starting point for new negotiations with North Korea.

\subsection{CTR Program in North Korea}

The CTR model is based on two elements: a strategy and a process. The success of the CTR strategy depends on compatible national interests, voluntary compliance, and transparency (DFI International: 8). The Nunn-Lugar CTR program originally provided funding and expertise for countries of concern, like the former Soviet Union, to decommission nuclear, biological, and chemical weapons stockpiles as agreed on by the Soviet Union and Russia.

After nuclear warheads were removed by the military from their delivery vehicles, Nunn-Lugar assistance provided equipment and supplies to destroy the missiles on which the warheads had been mounted, as well as the soils which had contained the missiles. Warheads were then eliminated, with the highly enriched uranium contained in them made into commercial reactor fuel that was purchased by the US under a separate program (Ksssenova, 2016).

As shown in the DFI International report, the process of CTR consists of the following six steps including umbrella agreements, which are agreements between the government of the United States of America and the government of the Russian Federation regarding cooperation in the area of nuclear material physical protection, control, and accounting, implementing agreements, requiring information, contracting process, execution/delivery, and audits \& examination (DFI International, 2001).

In sum, CTR has four key goals: to dismantle WMDs, to consolidate, and secure WMDs, related technology, and materials, to increase transparency and encourage higher standards of conduct, and to support defense and military cooperation in order to prevent proliferations of nuclear weapons. Since 2009, to uphold these principles, Nuclear Security Centers have been established in partner countries in order to increase training capability, consistent with international best practices, for nuclear security, material control, inventory management, transport security, and other activities important for improving nuclear security through coordination with the International Atomic Energy Agency (IAEA).

The CTR program was managed by the US Department of Defense, but also by the Department of Energy, and the Department of State, and had to provide the equipment for dismantlement and then to secure vulnerable materials, to strengthen physical security, to upgrade detection capabilities to prevent nuclear smuggling and to redirect thousands of former weapon scientists into civilian projects. 
Seen from such common ground on addressing nuclear-armed nations, the bottom line is that the organizational culture of various CTR participants could have a direct impact on the success, or lack thereof, of cooperative projects. In addition, in an environment of transition from an adversarial relationship to partnership, cooperation in the nuclear field remains extremely sensitive for both sides (Ksssenova, 2016).

To start a CTR program in North Korea requires an agreement between first of all, the Democratic People's Republic of Korea (DPRK) and the United States of America (USA), similar to the "Umbrella Agreement" signed in June 17, 1992, between the USA and the Russian Federation, through which the American government, under the CTR program provided funding and expertise to the partner country. In line with that, however, at the time of application of the relevant program to DPRK, in organizing a committee or meeting for the discussion of agreement, in particular, it would be advisable to restrict the number of participants, for example, to two or three other than the US and North Korea, adding South Korea as an observer.

The objective of the possible meeting is to convince North Korea of the US's resolution to solve the nuclear problem by CTR. In the process of hammering the resolution home into Pyongyang, it is crucial for Washington's position to forge a trustworthy relationship with the communist country. The transparency problem is also essential for making progress or for success of the CTR program, and for tracking down information about the numbers and locations of WMDs, which would ultimately contribute to a productive relationship between both participants. The principal meeting between the US and North Korea should be run parallel with the North-South dialogue, in which economic incentive elements need to be included to help redirect North Korean scientists to civilian jobs. Therefore, in the long run, South Korea should be positively engaged in the economic modernization of the people in the North in order to do away with the country's nuclear weapons. The importance of the South's positive engagement can be recognized from the Pakistan case, where, after Secretary of State, Powell's visit to Pakistan in 2004, the US provided \$100 million to the country as part of the CTR program, but has not made much progress because of the opposition of the people (Pedersen, 2015).

\subsection{Funding}

The Nunn-Lugar amendment of 1991 authorized the use in the 1992 fiscal year of $\$ 400$ million in US Department of Defense (DOD) funds to help the Soviet Union and its satellite countries destroy, transport, safeguard and not proliferate WMDs. The total budget for 2016 estimates the amount for the CTR program to be $\$ 358$ million (Pellerin, 2016). In Albania, the US provided in 2004 about $\$ 20$ million for two years to destroy its entire stockpile, 16tons of chemical weapons, which were believed to be of Chinese origin (Nguyen, 2004).

The US assistance is made possible by the Nunn-Lugar Expansion Act, signed by President George W. Bush in December 2003, which authorized use of up to $\$ 50$ million in CTR funds for nonproliferation activities outside the former Soviet Union, and the legislation introduced by Lugar that would further extend the use of such funds, would eliminate the $\$ 50$ million cap on the programs, and would transfer the authority for approving funds from the President to the Secretary of Defense. Regardless of the available American funds for CTR programs, for the Republic of Korea (ROK) as an opposing party of possible conflict with North Korea, it would be legitimate to contribute partly to the total funds needed for those programs.

Since August 1990, the ROK government has begun to raise funds to help cooperation between the North and South by adopting the Fund Law in 1990. The total amount of the cooperation fund whose sources are mostly from the government as of 2016, is 12,856,106 million Won (estimated USD \$107,13 million), as shown in the statistics below.

A third of the total is from government raised funds, and according to Budget Officer of the Ministry of Unification in South Korea, around 958 million Won (estimated USD \$800 million), which has been generated from the operating profit alone, could meet the expenses of the CTR. ${ }^{2}$ The Inter-Korean Fund statistics shows that an average of 494,500 million Won (estimated USD \$412 million) per year could be raised. An average government raised fund per year is 188,220 million Won, (about USD $\$ 157$ million). For the government to take advantage of the accumulated cooperation fund, at least $\$ 300$ million could be used as a fund for CTR, aside from $\$ 100$ million for humanitarian assistance and economic aids.

2 That was what the budget officer would say about the finances during the phone call with one of the authors, Kim on January $30,2017$. 
Inter-Korean Cooperation Fund

\begin{tabular}{|c|c|c|c|c|c|c|}
\hline Year & $\begin{array}{c}\text { Government } \\
\text { fund }\end{array}$ & $\begin{array}{c}\text { Non- } \\
\text { government } \\
\text { fund }\end{array}$ & $\begin{array}{l}\text { Deposit } \\
\text { received }\end{array}$ & $\begin{array}{c}\text { Operating } \\
\text { profit }\end{array}$ & $\begin{array}{c}\text { Total } \\
\text { accumulated } \\
(\text { KOR WON })\end{array}$ & $\begin{array}{c}\text { Total } \\
\text { accumulated } \\
(\text { US dollar)* }\end{array}$ \\
\hline Total & $4,893,803$ & 2,723 & $7,001,274$ & 958,306 & $12,856,106$ & 10713.42 \\
\hline 2016 & 92,500 & 1 & 207,000 & 27,399 & 326,900 & 272.41 \\
\hline 2015 & 93,203 & 238 & 90,500 & 19,863 & 203,804 & 169.84 \\
\hline 2014 & 93,400 & - & 228,600 & 47,304 & 369,304 & 307.75 \\
\hline 2013 & 105,500 & 3 & 530,000 & 162,300 & 797,803 & 664.84 \\
\hline 2012 & 112,800 & 2 & 400,000 & 51,236 & 564,038 & 470.03 \\
\hline 2011 & - & 2 & 104,400 & 38,276 & 142,678 & 118.9 \\
\hline 2010 & - & - & 875,000 & 51,238 & 926,238 & 771.87 \\
\hline 2009 & - & 56 & 81,000 & 74,354 & 155,410 & 129.51 \\
\hline 2008 & 650,000 & 52 & 147,500 & 49,274 & 846,826 & 705.69 \\
\hline 2007 & 500,000 & 75 & 584,591 & 38,859 & $1,123,525$ & 936.27 \\
\hline 2006 & 650,000 & 15 & 940,000 & 36,619 & $1,626,634$ & 1355.53 \\
\hline 2005 & 500,000 & 33 & 460,000 & 31,178 & 991,211 & 826.01 \\
\hline 2004 & 171,400 & 1 & 310,000 & 38,372 & 519,773 & 433.14 \\
\hline 2003 & 300,000 & 1 & 823,000 & 46,515 & $1,169,516$ & 974.6 \\
\hline 2002 & 490,000 & 77 & 505,000 & 42,035 & $1,037,112$ & 864.26 \\
\hline 2001 & 500,000 & 1,079 & 310,000 & 29,406 & 840,485 & 700.4 \\
\hline 2000 & 100,000 & 542 & 254,852 & 30,393 & 385,787 & 321.49 \\
\hline 1999 & - & 3 & 149,831 & 23,013 & 172,847 & 144.04 \\
\hline 1998 & - & - & - & 40,280 & 40,280 & 33.57 \\
\hline 1997 & 50,000 & 288 & - & 27,874 & 78,162 & 65.14 \\
\hline 1996 & 100,000 & 132 & - & 18,409 & 118,541 & 98.78 \\
\hline 1995 & 240,000 & 119 & - & 14,589 & 254,708 & 212.26 \\
\hline 1994 & 40,000 & 1 & - & 9,387 & 49,388 & 41.16 \\
\hline 1993 & 40,000 & 3 & - & 4,778 & 44,781 & 37.32 \\
\hline 1992 & 40,000 & - & - & 5,118 & 45,118 & 37.6 \\
\hline 1991 & 25,000 & - & - & 237 & 25,237 & 21.03 \\
\hline
\end{tabular}

(unit: million won)

Source: ROK Ministry of Unification, "Inter-Korean Cooperation Fund” (December 2016).

*added by authors: $\$ 1$ adjusted to 1200 won.

By the way, one can find an interesting difference between the amounts of government fund raising under the progressive regimes of the Kim and Noh administrations from 2000 to 2008; an average amount per year is 450,000 million Won, about $\$ 375$ million, but under the conservative one, especially under the current Park 
regime, the average amount of government-raised funds per year was 96,200 million Won, around $\$ 80.1$ million, less than half of the amount for those progressive regimes

Consider the case of Ukraine, which was left with an estimated 176 ICBMs and 14 nuclear reactors. The George H. W. Bush administration's pledge of $\$ 175$ million was more than the real costs. Potter maintains that the ROK can be fully charged with the cost of the CTR program in North Korea (Potter, 1995). The accumulated funds of ROK's own would make Potter's claim more feasible and valid in implementing the CTR program for North Korea.

Taking the yearly funding of the US Congress into account, where the lowest funding was $\$ 300$ million in FY 1996, and the highest was $\$ 528.5$ million in FY 2014, the annual funding by South Korea of $\$ 300$ million would be enough for the North Korean CTR (Walker, 2016). On top of that, according to Goldman and O'Kelly, the costs of LUE conversion and the spent fuel return are presumed to be between $\$ 7.5$ and $\$ 12$ million, taking 2-3 years (Goldman \& Sean, 2005).

Even the 5-megawatt Tongbyun reactor, which would cost billions of dollars, could be burdened with the collected civilian funding in South Korea. Kang, a nuclear scientist, has argued that the South Korean government expressed interest in the idea of the CTR program, and trained North Koreans during the KEDO projects to build the two LWSs. In 2002, the Korean Electric Power Company conducted a 13-week long training for 125 North Korean engineers (Kang, 2009). Again, recalling the previous experience of the South, in order to resolve the North Korean nuclear problems, it would be crucial for the South Korean government to already have economic resources as well as some technical capability in cooperation with the US to participate actively in the CTR programs for North Korea.

Though Sam Nunn who was a former Senator, Democrat and Richard Lugar who was a former Senator, Republican differed in their political party affiliations, they worked together as Senators, to realize the denuclearization or dismantlement of nuclear weapons in Russia and former Soviet Union territories, as mentioned above. They forged partnership in their efforts to non-proliferate, dismantle or destroy the nuclear weapons, to safeguard the nuclear materials in the US Senate. After their retirement from Senate, Lugar in 2007, Nunn in 1996, Lugar worked in the Lugar Center, a non-profit organization focusing on the nuclear non-proliferation problem and Nunn, beginning from 2001, organized Nuclear Threat Initiative ( NTI ), which was a non partisan, non profit organization, with the help of Ted Turner to deal with the problem of weapons of mass destruction.

Lugar took part in the USKI (United States-Korea Institute, School of Advanced International Studies of Johns Hopkins University) held conference under the title of "Policy Prescriptions for the North Korea Threats" in June 2017, and Nunn presented with Mike Mullen, his task force report to Council on Foreign Relations (CFR ), titled "A Sharper Choice on North Korea" in September 2016. Lugar take emphasis on the application of experiences and lessons learned from the case of dismantlement of nuclear weapons in the former Soviet Union territories to North Korean case, and Nunn, with his experiences in NTI, like Nuclear Security Projects and Nuclear Security Index, engaged in model programs to shape and implement to reduce the threats, and inspire privates and governments efforts to secure and manage the nuclear materials (Crowley, 2007). ${ }^{3}$

Particularly, Sam Nunn has presented his views on North Korean Nuclear issue several times since January 2017, starting from the statement for the record on U.S. Policy toward North Korea to the U.S. Senate's Foreign Relations Committee on Jan. 31, 2017. In this presentation, he indicated the growing capability of DPRK to strike U.S. with nuclear weapons, and the grave proliferation danger. He pointed out the key role of China in addressing this danger, which was negated by Trump himself in June (Lander \& Gardiner, 2017).

And in his interview with Wolf Blitzer of CNN on 24th of April, 2017, Nunn opined that US did not seem to have a strategy, though he acknowledged that the President is putting emphasis on the diplomatic option and on the UN. Nunn, in his interview on $25^{\text {th }}$ of April, he, putting the freeze of weapons and test of missiles on the part of North Korea as a goal, said US should have an informal bilateral talks with North Korea. He preferred to use "dialogue" instead of "negotiation", and direct talks and informal talks without preconditions" before going to negotiations.

\footnotetext{
3 Also, see Mariana Budjeryn, “Sen. Sam Nunn: We Have a Choice Between Cooperation or Catastrophe," Russia Matters, June 20, 2017, https://www.russiamatters.org/analysis/sen-sam-nunn-we-have-choice-between-cooperation-or-catastrophe (accessed July 1, 2017). In his interview with Mariana Budjeryn, a Stanton Nuclear Security Fellow at Harvard's Belfer Center on June 20, 2017, he presented first his visit to NATO Military Bases in 1962 gave him to think the real possibility of nuclear war and the way to prevent, second his visit to NATO in 1974 gave him the information about the largest amount of nuclear weapons and materials, and lastly, his trip to Moscow in August 1991, when Gorbachev was arrested by the Soviet military coup and was not in control of nuclear arsenal, as the background of his new thinking of CTR. And it would be necessary, he urged, to take advantage of learning from the US model of CTR and to apply it to North Korea on the basis of the experiences of the former Soviet Union.

${ }^{4}$ In the letter sent to President Trump from six prominent US government officials including William Perry, "informal" and "without precondition" were accentuated. They said it was "realistic option" and to be held " in the near future." See William Perry, "Top Former US Officials Urge President Trump to Begin Talks with North Korea," June 28, 2017, http://www.wjperryproject.org/notes-from-the-brink/top-former-us-officials-urge-president-trump-to-begintalks-with-north-korea (accessed July 10, 2017).

On that point it is notable to compare these words of Nunn with those of Rex Tillerson who told on April 27 the NPR the same content. See Michele Kelemen, "Trump Administration Wants North Korea at Negotiating Table on Nuclear Weapons," April 27, 2017, http://www.npr.org/sections/thetwoway/2017/04/27/525866684/trump-administration-wants-north-korea-at-negotiating-table-on-nuclear-weapons (accessed June 15, 2017).
} 
He proposed a multi-level talks, including talks between officials, and between military officials. In his presentation in the Senate in January, 2017, he made some recommendations to be included and implemented in parallel: first offer genuine incentives for North Korea to take part in substantive talks or negotiations, like peace agreement to end Korean war and the normalization of relations and to increase pressure or sanction on North Korea. He eventually suggested to strong sanctions like suspension of North Korea's credentials at the UN, and against military attacks of North Korea or refusal to negotiate, he suggested an active proportionate self-defense response, including inside North Korea.

\section{US-ROK Summit Talks and After}

In June 30, the two Presidents of U. S. and Republic of Korea, reaffirmed in Washington D.C., the mutual trust and shared value as allies, and also reaffirmed the their commitment to counter the growing threat to peace and security posed by North Korea's nuclear and ballistic missile program. And they pledged to continue closely to achieve the shared goal of denuclearization of Korean Peninsula in a peaceful manner.

They reaffirmed the two sides' shared top priority to resolve the nuclear issue and they do not maintain a hostile policy toward North Korea and together, stand ready to offer a bright future for North Korea if it chooses the right path.

And the two leaders emphasized that the door to dialogue with North Korea remains open under the right circumstances, and President Trump supported the ROK's leading role in fostering an environment for peaceful unification of the Korean Peninsula (Yonhap News Agency, 2017). ${ }^{5}$

It is generally acknowledged that President Moon had a good result in his diplomacy with the U.S. by his first visit to Washington, except the burden-sharing problem and trade. But it is to be reminded that there remains lots of obstacles to overcome in the relations with North Korea. First, North Korea adamantly reiterated their insistence that the nuclear issue is the matter of concern between U.S. and North Korea (Yonhap News Agency, 2017). According to Yonhap news, Nodong shinmun ran an article saying that South Korea has no cause to interfere and that the issue did not have any relations with the South-North relations.

Second, though South Korea obtained a support from the U.S. in playing a leading role in fostering an environment for peaceful unification, that unification could not but depend on the resolution of nuclear issue. At most, the possible means of fostering the relaxation of tensions, and if possible the confidence building measures which support the stability and security of the peninsula, could be discussed between the two Koreas.

It's imperative, first of all, to have a dialogue, and to make a progress in the relations between the two. It is to have a plan, or roadmap, not strategy, if one takes into account the four principles which were declared in the special address of President Moon on June 30 in CSIS.

The four principles in the policy for North Korea are, first, No antagonistic policy to DPRK, second, No military attack to North Korea, third, No Regime change or collapse of North Korea, and fourth, No intentional acceleration in the process of unification of Korea (Seoul Daily, 2017).

And President Moon, during his participation in G-20 Conference held in Germany, on July 6, 2017 made a declaration in his address that he would pursue a peace treaty to end a war with North Korea, taking a step forward for reconciliation and he would take a comprehensive approach to North Korea's nuclear issues. He reconfirmed President Trump's reassurance and support in his intention to have a dialogue and inter-Korean exchanges with North Korea, though under certain condition (Korea Times, 2017). While he mentioned human rights records of United Nations about North Korea, he also took emphasis on humanitarian aid for civilians.

Though the CTR approach to Korean peninsula's denuclearization problem does not raise a serious problem in its development of technical process of denuclearization, the essential question for this approach is how to lead North Korea to its bargaining table. It is generally understood among concerned parties that all the sanctions including UN are to lead North Korea to the diplomatic table. After his inauguration of supreme leader in North Korea, Kim Jung-un made a dozen missile tests in 2017 only and three nuclear tests since December 2011.

After his July $4^{\text {th }}$ missile test, he expressed it as his present to America on the Independence Day. But as irony would have it, it was the $45^{\text {th }}$ anniversary of the 7.4 South-North Joint communique, which proclaimed the independent and peaceful unification of Korea in national unity. It raised the debate on the nature of the missile among Russians who insisted that that was not ICBM as proclaimed by Americans. Russians were insisted that the missile was not ICBM but Intermediate Range Ballistic Missile (IRBM).

The difference in their conceptions surrounding the deterrence resulted in their evaluation of the nature of that missile. From the claimers of Russian deterrence, the purpose of North Korea's missile test was to assure their capability of targeting US bases and Allies in the North East Asia, not targeting US mainland. According to a media report, the $6^{\text {th }}$ test of nuclear bomb is on the list.

${ }^{5}$ For full text of the joint statement issued by South Korea, see “Korea, U.S. Issue Joint Summit Statement,” Yonhap News Agency (2017). 
NYT reported, citing a report issued by 38 North, a research Institute of John's Hopkins University, Joseph Bermudez said "The rugged test site appeared able to conduct a sixth nuclear test, at any time upon receiving order" (Broad, 2017). After the launching of ICBM or IRBM on July 4, lots of American scholars have expressed a pessimistic view, like Sue Mi Terry, a former CIA analyst (NPR, 2017) and some of the hawkish consultants like Michael Auslin, a Williams-Griffith Fellow, take a very negative attitude toward North Korea (Auslin, 2017).

Besides the recent worsening situation for solving the North Korean nuclear issue, another obstacle was to be overcome is what Michael Krepon pointed out in his book, "Cooperative Threat Reduction, Missile Defense, and the Nuclear Future" (Krepon, 2003). Krepon, while analyzing the policy transitions from Mutual Assured Destruction to CTR in strategic arms control, placed Cooperative Threat Reduction in his third transition period after the second transition period in which Reagan Administration put emphasis on strategic arms reduction. Through the three transition period, according to Krepon, there was a persistent debate among scholars and government officials about the military policy surrounding strategic arms control (2003: 249250).

"Dominators", a prevailing group formed by government officials and republican party's inclination, insisted US's nuclear superiority putting emphasis on the military activities, missile defense, based on the nonproliferation, for example, like a "National Posture Review released in 2002 in Bush Administration (2003: 106-113). On the other hand, "Conciliators " under the review from future perspective, dis-equilibrium should be changed, putting emphasis on treaties, cooperation among states, and diplomacy with persuasion based on trust among states, forming a coalition and partenership (2003).

After Presidential election in 20oo, Dominators are prevailing, acting with unilateral and military actions, sloughing off the treaties restraining military flexibility. Criticized by Conciliators, Dominators are changing to form a coalition to prevent the isolation from the Allies, which was caused by putting too much value on the missile defense.

As mentioned above, the deterrence concept was crucial in its relations with China and Russia particularly in the pursuit of non-proliferation. Krepon claimed that China, Russia, take into account the deterrence as a capability to give minimal destruction to US in the days of US superiority in nuclear, conventional forces including missile defense (2003: 187-189). It is highly possible to presume that North Korea would come up to negotiation table, with in a year, when they think they secured the deterrence, or when they are ready to talk with strong hand to US by assuring their strong strategic position with their Hwasong-14, or Pukkuksong 1, 2 missiles. It would be a good guide to assess the recent North Korean missile tests and their future direction of missile development. It is notable that recently the President of Council on Foreign Relations, Richard Hass, proposed, after considering three alternatives, first, reluctant acceptance of North Korea as nuclear state, second, use of military attacks, third, multilateral negotiations, like six-party talks, to try diplomacy first on North Korea (Haass, 2017).

It is important to note that Haas, presumed to belong to Dominators, has proposed "diplomacy", which is the essential instrument of conciliators. It is also remarkable that Choe Son-hui, director-general of the North America affairs of North Korean Foreign Ministry, told reporters in at the Beijing Capital International Airport in May 2017, that North Korea would hold dialogue under right conditions with the new US administration (Stanglin, 2017).

\section{Concluding Remarks}

It was actually Kim Jung-il who concluded the Agreed Framework with the US on October 21, 1994, after Kim Il-sung's death on July 8, 1994. It may be said that Kim Jung-un just followed the will of Kim Jung-il in his pursuit of nuclear weapons, and then it would be better to remember that it was also Kim Jung-il who wanted to normalize diplomatic relations with the US by dispatching General Cho Myung-rok as his personal special envoy to meet President Clinton on October 10, 2000.

Recently, a South Korean expert on the North Korean nuclear problem revealed that North Korea is presumed to have 45 nuclear weapons and also the nuclear materials of $52 \mathrm{~kg}$ of plutonium and $280 \mathrm{~kg}$ of $\mathrm{HEU}$ (Sooyeon, 2017). In addition, in October 2008, the ROK Defense Ministry estimated that North Korea might have between 2,500 and 5,000 metric tons of chemical weapons with 150 warheads for ballistic missiles (Bermudez, 2013).

While celebrating the 25 $5^{\text {th }}$ Anniversary of the Nunn-Lugar CTR program on May 9, 2016, Carter praised the forward-looking statement that helped make the historic change. As he said, it was brand-new thought which might be paradoxical to some, and it was controversial, but the two senators, irrespective of their political parties, made a global breakthrough in the nuclear weapons field. It is only the USA that has expertise and funding for a CTR program and the only success history of denuclearization. In their testimony to the Senate Committee on Foreign Relations, on January 31, 2017, Nicholas Eberstadt emphasized working with allies, but acting unilaterally, at the same time, arguing that the US can bluff then mitigate, and eventually eliminate the WMDs of North Korea by Threat Reduction Eberstadt (2017).

With emphasis on US-ROK close coordination, as a way of dealing with the North Korean threat, Scott Snyder has very recently recommended dispatching a special envoy and separating the North Korean problem 
from other contentious issues in US-China relations, though not apparently mentioning the CTR program (Snyder, 2017).

With the comprehensive approach to North Korea's nuclear problem including the CTR program, the US and the ROK should jointly organize the denuclearization of the Korean peninsula and consequently peace as well as stability in north-east Asia. As explained by Senator Lugar after 20 years, "No one would have predicted in the 1980 s that Americans and Russians would be working together to destroy weapons in the former Soviet Union, and the Nunn-Lugar Program can be applied around the world" (NPR, 2017).

Keeping the significance of the Nunn-Lugar's CTR program and the close US-ROK cooperation in mind, it would be a good concluding remark to reiterate what the designated US Secretary of Defense said in his Senate confirmation hearings, on 12 January 2017, that his primary mission at the Pentagon would be allowing the State Department to negotiate from a "position of strength" to avoid conflict in an era of rapidly evolving world wide threats to work with and strengthen our alliances (Steele, 2017).

It is irony to see the South Korea's Central Bank's revelation that North Korea's economy grew 3.9percent in 2016, its fastest pace in 17 years. Despite of international sanctions due to the nuclear development program since 2006 and food shortages, overall exports from North Korea also rose to $\$ 2.82$ billion thanks to the fishery products (Reuters, 2017).

\section{References}

Auslin, M. (2017). Defending Homeland from North Korean threat must be top priority, the hill. Retrieved from: http://thehill.com/blogs/pundits-blog/defense/343098-opinion-defending-homeland-from-north-koreanthreat-must-be-top. $\ulcorner$ Accessed July 25, 2017].

Bermudez, J. (2013). North Korea's chemical warfare capabilities, 38 North. Retrieved from: http://38north.org/2013/10/jbermudez101013/. [Accessed January 11, 2017].

Bleek, P., Chen, K., \& Joshua, P. (2016). Elimination of weapons of mass destruction: Lessons from the last quartercentury. Nonproliferation Review, 23(1-2), 15-23.

Bosworth, S. (2012). Reflections on KEDO. Retrieved from: http://38north.org/wpcontent/uploads/2012/11/Transcript_Bosworth0619121.pdf. [Accessed January 9, 2017].

Broad, W. (2017). Activity spotted at North Korea nuclear test site, New York Times. Retrieved from: https://www.nytimes.com/2017/04/19/world/asia/north-korea-nuclear-test-volleyball.html. [Accessed July 1, $2017]$.

Carter, A. (2005). Origins of the Nunn-Lugar program.

Carterr, \& William, P. (2000). Preventive defense: A new security strategy for America. Washington, D.C: Brookings Institution Press.

Cerami, J. R. (2005). From the six-party talks to a Northeast Asian security regime?: Cooperative threat reduction strategies and institutional development. Pacific Focus, 20(1), 7-57.

Crowley, M. (2007). The stuff Sam Nunn's Nightmares are made of, New York Times Magazine. Retrieved from: http://www.nytimes.com/2007/02/25/magazine/25Nunn.t.html. [Accessed June 1, 2017].

DFI International. (2001). The future of the cooperative threat reduction program. Retrieved from: www.globalsecurity.org/wmd/library/report/2001/ctrreport.doc. [Accessed 10 January 2017].

Eberstadt, N. (2017). From "engagement" to threat reduction: Moving toward a North Korea strategy that works. Retrieved from: http://www.foreign.senate.gov/imo/media/doc/013117_Eberstadt_Testimony.pdf. [Accessed February 10, 2017].

Goldman, I., \& Sean, O. (2005). Possible cooperative projects for utilization of the DPRK's IRT-200 research reactor. Retrieved from: http://sites.nationalacademies.org/cs/groups/pgasite/documents/webpage/pga_057020.pdf. [Accessed January 30 2017].

Haass, R. (2016). The coming confrontation with North Korea.

Haass, R. (2017). Try diplomacy first on North Korea, even though it probably won't work, USA today. Retrieved from: https://www.usatoday.com/story/opinion/2017/07/11/try-diplomacy-first-north-korea-richard-haasscolumn/460538001/. [Accessed July 20, 2017].

Harrington, A., \& Joseph, D. T. (2010). Organizational options for redirecting DPRK nuclear experts.

Kang, J. (2009). Redirecting North Korea's Nuclear workers. Bulletin of the Atomic Scientists, 65(1), 48-55.

Kim, O. (2016). Visiting China, N. Korean official says no plans to discuss denuclearization, Hankyoreh.

Kirk, D. (2017). Trump appointees rattle rockets. Retrieved from: http://www.asiasentinel.com/politics/donald-trumpappointees/. [Accessed February 22, 2017].

Korea Times. (2017). President to pursue peace treaty with N. Korea, despite ICBM.

Krepon, M. (2003). Cooperative threat reduction, missile defense, and the nuclear future. New York: Palgrave Macmillan.

Ksssenova, T. (2016). Implementing nonproliferation programs: The cooperative threat reduction process in the former soviet union, in Jeffrey W. Knopf, ed., International Cooperation on WMD Nonproliferation. Georgia: University of Georgia Press.

Lander, M., \& Gardiner, H. (2017). China falls short on curbing North Korea, Trump says, New York Times. Retrieved from: https://www.nytimes.com/2017/06/20/world/asia/trump-china-north-korea.html. [Accessed July 10, $2017]$.

Lugar, R. G. (2016). WMD elimination lessons learned. Nonproliferation Review, 23(1), 25-29.

Miller, S. (1995). Cooperative threat reduction: Summary of drafting panel discussion.

National Academy of Sciences. (2009). Global security engagement: A new model for cooperative threat reduction. Washington, D.C: National Academies Press.

Nguyen, M. (2004). Albania to receive nunn-lugar assistance. Retrieved from: https://www.armscontrol.org/act/2004_12/Albania. [Accessed January 11,2017]. 
NPR. (2017). US look to revive talks on North Korea's nuclear program. Retrieved from: http://www.nti.org/analysis/articles/nunn-lugar-vision-20-years-reducing-global-dangers/. [Accessed January $10,2017]$.

Pedersen, C. (2015). The expansion of cooperative threat reduction programs: The case for a formalized agreement with Pakistan. Pepperdine Policy Review, 8(1), 1-17.

Pellerin, C. (2016). Carter: Threat reduction program was novel response to historic change, DOD News. Retrieved from: https://www.defense.gov/News/Article/Article/7552 16/carter-threat-reduction-program-was-novel-responseto-historic-change. [Accessed January 15, 2017].

Perry, W. (2017). What to do about a North Korean ICBM. Retrieved from: http://38north.org/wpcontent/uploads/2017/01/2017-0 109-38-North-Press-Briefing-Transcript.pdf. [Accessed February 16, 2017 ].

Potter, W. (1995). The politics of nuclear renunciation: The cases of Belarus, Kazakhstan, and Ukraine. Washington, DC: Henry L. Stimson Center.

Reuters. (2017). North Korea's economic growth climbs to 17-year high in 2016 despite sanctions targeting nuclear program. Retrieved from: http://www.cnbc.com/2017/07/20/north-koreas-economic-growth-climbs-to-17year-high-in-2016-despite-sanctions-targeting-nuclear-program.html. [Accessed July 22, 2017].

Seoul Daily. (2017). President moon, declare the four principles in the policy toward North Korea.

Snyder, S. (2017). Confronting the North Korean threat: Reassessing policy options, CRF. Retrieved from: http://www.foreign.senate.gov/imo/media/doc/013117_Snyder_Testimony.pdf. [Accessed 15 February 15, 2017 .

Sooyeon, N. K. (2017). Presumed to be holding $280 \mathrm{~kg}$ of highly enriched uranium: Export, Yonhap News agency. Retrieved

from:

http://english.yonhapnews.co.kr/northkorea/2017/02/09/0401000000AEN20170209006251315.html. [Accessed February 15, 2017].

Stanglin, D. (2017). North Korea would talk with Trump administration under 'right conditions', USA Today. Retrieved from: https://www.usatoday.com/story/news/2017/05/13/north-korean-diplomat-says-talks-us-possibleunder-right-conditions/101631744/. [Accessed July 20, 2017].

Steele, J. (2017). Mattis as defense secretary: It's good to be back. Retrieved from: http://www.military.com/dailynews/2017/01/22/mattis-wastes-no-time-defense-secretary-it-good-be-back.html. [Accessed February 15, 20177.

Walker, P. F. (2016). Cooperative threat reduction in the former Soviet states: Legislative history, implementation, and lessons learned. The Nonproliferation Review, 23(1-2), 115-129.

Washington Post. (2016). Why I voted for Trump. Washington Post.

Wit, J., Wolfsthal, J., \& Choong-suk, O. (2005). The six party talks and beyond: Cooperative threat and North Korea.

Yonhap News Agency. (2017). North Korea to repeat the claim that the nuclear issue is a matter between North Korea and U.S. ahead of U.S-Korea Summit Talks. 